Research Article Human and Medical Genetics

\title{
Molecular characterization of mitochondrial Amerindian haplogroups and the amelogenin gene in human ancient DNA from three archaeological sites in Lambayeque - Peru
}

\author{
Jorge Victor Wilfredo Cachay Wester ${ }^{1}$ (D), Vanny Judith Soplapuco Vilchez ${ }^{2}$, \\ Carlos Eduardo Wester La Torre ${ }^{3,4}$ and Luis Alberto Rodriguez-Delfin ${ }^{2}$ \\ ${ }^{1}$ Universidade de São Paulo, Faculdade de Medicina de Ribeirão Preto, Departamento de Genética, \\ Laboratório de Genética Humana e Médica, Ribeirão Preto, SP, Brazil. \\ ${ }^{2}$ Universidad Nacional Pedro Ruiz Gallo, Facultad de Ciencias Biológicas, Departamento de Biología, \\ Laboratorio de Genética y Biología Molecular, Lambayeque, Peru. \\ ${ }^{3}$ Museo Nacional de Arqueología y Etnología Brüning, Lambayeque, Peru. \\ ${ }^{4}$ Universidad Nacional Pedro Ruiz Gallo, Facultad de Ciencias Histórico Sociales y Educación, \\ Departamento de Arqueología, Lambayeque, Peru.
}

\begin{abstract}
Important pre-Inca civilizations, known by their great political and religious structures, inhabited the northern coast of Peru. Archeological and anthropological studies have shown that people from these villages have hierarchical strata, but the genetic structure has been poorly studied. Here, we aimed to perform a molecular characterization of the Amerindian maternal lineages and the amelogenin gene in skeletons collected from three archeological sites in Lambayeque. Ancient DNA (aDNA) samples were analyzed with conventional PCR to assess the nine-base pair (9 bp) deletion corresponding to mitochondrial haplogroup $B$ and the identification of haplogroups $A, C$, and $D$ were obtained with PCR-RFLP experiments. The sex was characterized via amplification of the $A M E L(X / Y)$ locus. Haplogroup frequencies were compared with available data from other ancient and modern civilizations from the Peruvian coast and highlands using statistical methods. Our results showed that haplogroup $C$ had the highest frequency, while haplogroup B showed variable diversity in the analyzed populations. The meta-analysis revealed a positive correlation among some coastal villages. We concluded that ancient populations analyzed in our study showed the presence of four Amerindian mitochondrial haplogroups, which is consistent with previous studies.
\end{abstract}

Keywords: Ancient DNA, AMEL (X/Y) locus, Amerindian haplogroup, Peru.

Received: August 12, 2019; Accepted: October 05, 2020.

\section{Introduction}

Lambayeque is located on the northern coast of Peru. This place was an important socio-political center for ancient pre-Inca civilizations such as Moche (100 C.E.-700 C.E.), Sipan (250 C.E.), Sican (900 C.E.-1100 C.E.), and Lambayeque (Naylamp) (700 C.E.-1375 C.E.). Three ancient empires (Chimu, Wari, and Inca) used these lands to control the exchange of agricultural products through the coast, and the remains of its populations have been studied because of their exceptional mortuary practices (Shimada et al., 2004).

Lambayeque people occupied the Jequetepeque valley, Pomac, and Chotuna-Chornancap between 700 and 1375 C.E. (Wester La Torre et al., 2014; Klaus et al., 2016). This civilization was initially identified as part of the Sican culture, but new archeological and anthropological evidence has pointed to the existence of a well-structured socio-political civilization that preceded Sican, and its rise coincided with the end of Moche culture (Klaus and Tam, 2009). The expansion

Send correspondence to Jorge Victor Wilfredo Cachay Wester. Universidade de São Paulo, Faculdade de Medicina de Ribeirão Preto, Departamento de Genética, Laboratório de Genética Humana e Médica, Avenida Bandeirantes, 3900, 14049-900, Ribeirão Preto, São Paulo, SP, Brazil. E-mail: jwester@ usp.br. of the Lambayeque civilization toward the Jequetepeque valley also indicated that there was a migration process to the south of the northern coast and to the highlands due to political and economic reasons. Therefore, there is a possibility of admixture with other civilizations (Castillo and Donnan, 1994) in such a way that it is important to study the genetic structure of this population.

The first molecular study in American populations using mitochondrial DNA established the presence of four Amerindian mitochondrial haplogroups named A, B, C, and D (Torroni and Wallace, 1995). In South America, these four haplogroups are well distributed. Several studies on mitochondrial haplogroups have been performed among native ancient South-American populations (Merriwether et al., 1994, 1995; Moraga et al., 2001; Eshleman et al., 2003), which have reported the presence of these four haplogroups.

Molecular analysis of ancient human burials from the central Andes determined that haplogroup B has the highest frequency in Andean populations (Shinoda et al., 2006; Fehren-Schmitz et al., 2010; Valverde et al., 2016). In modern populations, similar haplogroup frequencies are observed in regions located in the central south of Peru and the north of Bolivia (Cabana et al., 2014). In addition, haplogroups $\mathrm{C}$ and 
D have been found in samples from the coast and the Amazon (Sandoval et al., 2013).

Mitochondrial DNA analysis of ancient populations from the south coast of Peru revealed diachronic variations in the matrilineal genetic composition of the analyzed area, which correlate with the cultural events that occurred in the period of the development of these civilizations (Fehren-Schmitz et al., 2010). Meanwhile, the ancient northern coast populations seem to have a close matrilineal structure (Shimada et al., 2004). To investigate the maternal relationships around the ancient Peruvian coast and highlands, we aimed to study the maternal heritage and the amelogenin gene by using ancient DNA obtained from human remains of three archeological sites in Lambayeque.

\section{Material and Methods}

\section{Samples}

Teeth samples from ancient human remains of 32 people buried in three archeological sites located in the Lambayeque valley (Figure 1) were collected at the National Museum of Archaeology and Ethnography Hans Heinrich Brüning, with the permission of the Ministry of Culture from Peru. One of the archeological sites is the Chapel of San Pedro de Morrope, located in the city of Morrope. At this site, there are tombs containing skeletons of several individuals that came from native villages in Lambayeque, belonging to the pre-colonial period. The second site is the Huaca Cascajales located in the city of Eten, which served as a sanctuary for low-middle status ancient people in the late Lambayeque period. The third site is the Huaca Tanque Nuevo located in La Caleta de San Jose town, which was an ancient cemetery used during the Chimu period for local native fishers (Table 1). Skulls and pelvic bone samples from all subjects found at excavations in San Jose and Morrope were used for bioanthropological analysis, and the results were previously published (Klaus et al., 2009; Klaus and Tam, 2009). Hence, samples from Eten passed through routine analysis at the National Museum of Archaeology and Ethnography Hans Heinrich Brüning. In addition, only teeth samples were used for molecular analysis in this study (Figure 2).

\section{Precautions to avoid DNA contamination}

Samples were handled by only one person who performed the collection of the samples, pretreatment, and molecular analysis of mitochondrial haplogroups. Full body protective clothing, facemask, and several layers of gloves were worn during the pretreatment. The molecular biology laboratory worked with ancient DNA (aDNA) samples only, and any modern sample was not processed in this laboratory. The DNA extraction, pre-PCR, and post-PCR sample were processed at different work places that were irradiated with UV for at least 40 min and cleaned carefully. Strict workflow protocols for ancient DNA analysis were performed during lab work. Teeth were soaked in a $13 \%$ sodium hypochlorite solution for $15 \mathrm{~min}$, rinsed once with ddH2O and $95 \%$ ethanol, and dried in a UV-irradiated box. Experiments were performed on duplicate tooth samples from each individual, and the
DNA of the person who manipulated the samples was also processed in all the analyses. Negative controls were used during the extraction and PCR experiments. We performed DNA extractions without sample and PCR reactions without DNA.

\section{DNA extraction}

About $1 \mathrm{~mm}$ of the dentin layer was removed using a dental drill, and samples were rinsed, soaked, rinsed again, and then dried as described above. Then, the teeth were pulverized in liquid nitrogen and digested in $12 \mathrm{~mL}$ of EDTA (0.5 M, pH 8) (PROMEGA, Madison, WI, USA) and $70 \mu \mathrm{L}$ of proteinase $\mathrm{K}(100 \mathrm{mg} / \mathrm{mL})$ (PROMEGA) for $18-24 \mathrm{~h}$ in a rotating hybridization oven at $55^{\circ} \mathrm{C}$. Samples were centrifuged at $7500 \mathrm{rpm}$ for $10 \mathrm{~min}$ and the supernatant was collected in a new autoclaved tube. Genomic DNA was extracted and eluted in a final volume of $100 \mu \mathrm{L}$ using High Pure DNA Extraction for PCR Kit (Roche, Basel, Switzerland), according to the manufacturer's instructions.

\section{PCR and PCR-RFLP analysis}

Mitochondrial DNA regions where the polymorphisms that define the Native American haplogroups and the amelogenin locus are located (AMEL $X / Y)$ were amplified by conventional PCR as previously described (RodriguezDelfin et al., 2001; Morikawa et al., 2011). Primer sequences and PCR fragments are shown in the supplementary material (Tables S1-S2 and Figure S1). Polymorphisms were detected by submitting the PCR products to enzymatic reactions for haplogroups A (+663) using HaeIII (PROMEGA), C (-13259) using HincII (PROMEGA), and D (-1571) using AluI (PROMEGA). Haplogroup B was detected through the 9 bp deletion. Multiplex PCR was performed to amplify $A M E L X$ (114 bp) and AMELY (120 bp). Amplified and digested fragments were analyzed by non-denaturing $6 \%$ polyacrylamide gel, followed by silver staining (Figure S1).

\section{Statistics and meta-analysis}

Haplogroup frequencies were obtained using the direct counting method. Hence, relative haplogroup frequencies were computed by mere counting (Tables S3-S5) and the intra-population genetic diversity index $\left(h_{\text {sk }}\right)$ within standard deviations, the fixation index $\left(F_{\text {st }}\right)$, and Nei's distance $(d)$ were determined using Arlequin version 3.5 (Excoffier and Lischer, 2010). Haplogroup frequencies were analyzed through Pearson's correlation and principal component analysis (PCA) among populations using R "correlation" (Lüdecke et al. 2019) and FactoMineR (Lê et al., 2008) packages, respectively. Cluster analysis was performed by comparing the two main clusters in average linkage (UPGMA) using the hclust package in R. In addition, analysis of molecular variance (AMOVA) was performed for each cluster of populations and among all populations using Arlequin version 3.5, in order to obtain the source of variation. Haplogroup frequency data from previously published studies (Fuselli et al., 2003; Lewis Jr. et al., 2007) were used for statistical analysis. 


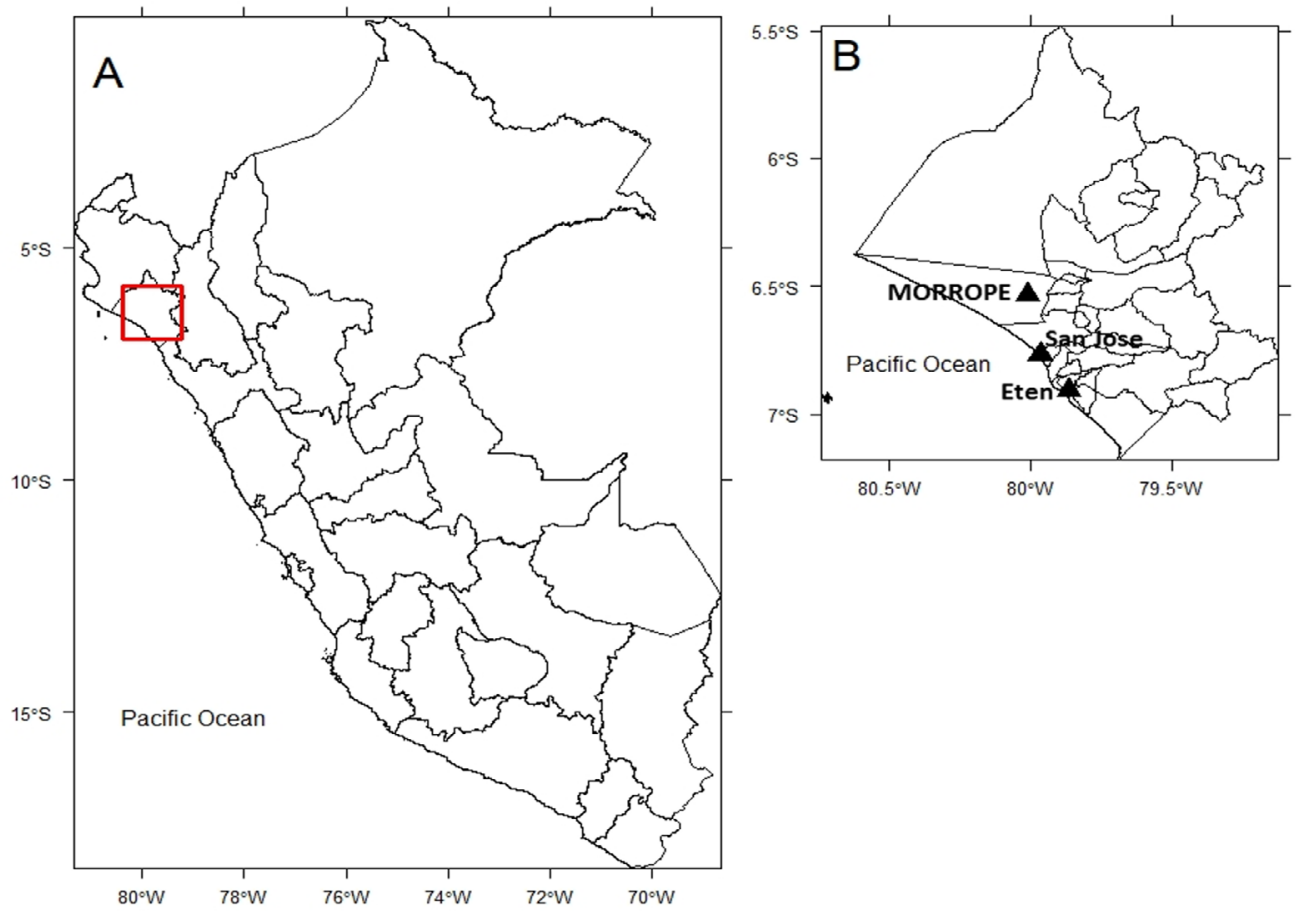

Figure 1 - Geographical localization highlighting the three archaeological sites. (A) Political map of Peru; (B) Political map of Lambayeque. Geographical coordinates of latitude and longitude were used to plot the localization of the archaeological sites, represented by black triangles.

Table 1 - Amerindian haplogroups relative frequencies and Intra-populational Genetic Diversity $\left(h_{\mathrm{sk}}\right)$ in three archeological sites from Lambayeque.

\begin{tabular}{|c|c|c|c|c|c|c|c|c|}
\hline \multirow{2}{*}{ Period } & \multirow{2}{*}{ Year (C.E.) } & \multirow{2}{*}{ Population } & \multirow{2}{*}{$\mathrm{n}$} & \multicolumn{4}{|c|}{ Relative frequencies } & \multirow{2}{*}{$h_{s k}$} \\
\hline & & & & A & $\mathrm{B}$ & $\mathrm{C}$ & $\mathrm{D}$ & \\
\hline Late Lamb. & $1100-1375^{\mathrm{a}}$ & Eten & 12 & 0.083 & 0.25 & 0.5 & 0.167 & $0.7121 \pm 0.1053$ \\
\hline Chimu & $1375-1475^{\mathrm{a}}$ & San Jose & 5 & 0.2 & 0.4 & 0.4 & 0 & $0.8000 \pm 0.1640$ \\
\hline Pre-colonial & $1536-1640^{\mathrm{a}}$ & Morrope & 15 & 0 & 0.333 & 0.667 & 0 & $0.4762 \pm 0.0920$ \\
\hline
\end{tabular}

${ }^{a}$ Samples were dating by radiometric techniques. This information was obtained from Klaus et al., 2009; Klaus and Tam, 2009
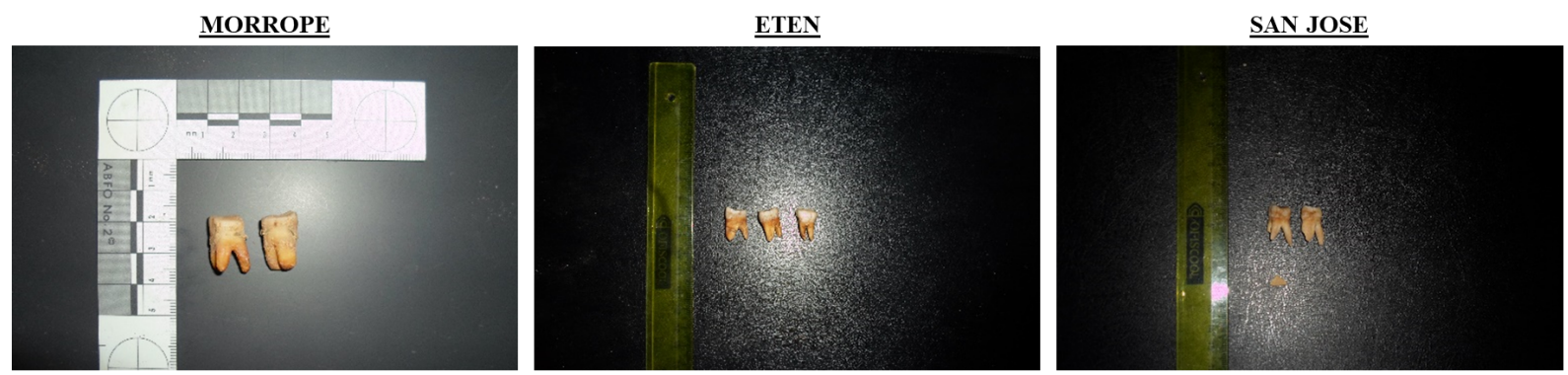

Figure 2 - Samples collected in the archaeological sites. Teeth were collected from archaeological sites at Chapel San Pedro de Morrope (MORROPE), Huaca Cascajales (ETEN), and Huaca Tanque Nuevo (SAN JOSE).

\section{Results}

Amelogenin gene analysis showed that, of the 32 samples, nine were female and seven were male. The sex could not be characterized for half of the samples. Molecular analysis of the 32 samples resulted in the identification of the four founder Amerindian haplogroups A, B, C, and D. Haplogroup $\mathrm{C}$ showed the highest frequency (50\%) in Eten. In addition, haplogroup B was present in $25 \%$ of this population. Morrope showed frequencies of $66.7 \%$ for haplogroup $\mathrm{C}$ and
$33.3 \%$ for haplogroup B. San Jose presented $40 \%$ of analyzed samples for each haplogroup B and C. Frequencies for both haplogroups $\mathrm{A}$ and $\mathrm{D}$ were lower in the three populations. The genetic diversity index was different in Morrope when compared with that in both San Jose and Eten, which suggests potential haplogroup diversity among the Lambayeque villages (Table 1).

We investigated the mitochondrial haplogroup frequencies of Peruvian ancient and modern civilizations 
previously reported from the coast and the highlands (Table 2). Correlation analysis showed a strong relationship between two of the northern coast populations analyzed in this study (Eten and Morrope), and we observed that there is a positive correlation with some coastal populations such as Nasca-Rural (Palpa), Nasca-Urban (Palpa), and Middle Horizon (Palpa). This suggests a similar frequency of the four haplogroups among these civilizations. We also observed a negative correlation between our samples and ancient highlands populations studied by Shinoda et al., 2006, which divided our data into two sub-groups: one for the coast and another for the highlands (Table 3).

Two main clusters were obtained from hierarchical clustering analysis using a bootstrap with more than 10,000 permutations to ensure the accuracy of the observations (Figure 3). We observed that haplogroup frequencies divided all populations into three sub-groups. The first sub-group comprised our three populations and one population from the highlands (Tayacaja). Indeed, Eten and Morrope have a close genetic distance, but San Jose appears to be closer to a Central Andes population. The second comprised different populations from the south without any cultural relationship. The third grouped the majority of Nazca populations as reported previously, and surprisingly, a northern coast population previously described was incorporated in this cluster.

The distribution of haplogroups $\mathrm{C}$ and $\mathrm{D}$ in the Peruvian coast is remarkable. An estimation of the population structure using principal component analysis (PCA) revealed a shared pattern among coastal populations in contrast to highland populations in which the prevalence of haplogroup B is strong (Figure 4). In addition, AMOVA showed that there was approximately $10 \%$ genetic variation among coastal populations, and this value decreased when villages from the north coast were grouped and compared with their counterparts from the south. Low $F_{\text {st }}$ values were obtained (Table 4), which were confirmed by computed Nei's distance (d) (Figure 5).

\section{Discussion}

Here, we present new data on the distribution of four Amerindian mitochondrial haplogroups in ancient coastal populations from Peru and sex characterization, using the $A M E L$ gene. Our results showed that ancient northern coast civilizations analyzed in this study had a different pattern of mitochondrial haplogroup frequencies when compared with ancient populations from the highlands. This may have been due to admixture of Ecuadorian and Peruvian northern coast individuals, which increases the variability of mitochondrial genetic legacy (Shinoda et al., 2006). In addition, new data revealed that the differentiation of northern and southern ancient Andean populations can be explained by cultural and geographical factors leading to population structural differences (Nakatsuka et al., 2020). The distribution of haplogroup frequencies in the three populations analyzed in this study demonstrated that the non-exclusive presence of haplogroup B increased after Spanish colonization. Among the four principal Amerindian lineages, haplogroup B has the highest diversity and polymorphism, which can explain the increase in maternal lineages in the highlands of Peru. Moreover, in the Peruvian coast, the maternal heritage is not exclusive for just one mitochondrial haplogroup (FehrenSchmitz et al., 2010).

Table 2 - mtDNA haplogroup frequencies in ancient and modern populations from the Peruvian coast and highlands

\begin{tabular}{|c|c|c|c|c|c|c|c|c|c|}
\hline \multirow{2}{*}{ Location } & \multirow{2}{*}{ Population } & \multirow{2}{*}{ Period } & \multirow{2}{*}{$\mathrm{n}$} & \multicolumn{5}{|c|}{ Haplotype frequencies (\%) } & \multirow{2}{*}{ Author } \\
\hline & & & & A & $\mathrm{B}$ & $\mathrm{C}$ & $\mathrm{D}$ & others & \\
\hline \multirow[t]{9}{*}{ Coast } & Eten & MH & 12 & 8.3 & 25 & 50 & 16.7 & 0 & This study \\
\hline & Morrope & LH & 15 & 0 & 33.3 & 66.7 & 0 & 0 & This study \\
\hline & San Jose & MH & 5 & 20 & 40 & 40 & 0 & 0 & This study \\
\hline & Ancient north coast & MH & 36 & 19.4 & 22.2 & 5.6 & 30.6 & 22.2 & Shimada et al., 2004 \\
\hline & Paracas (Peninsula) & $\mathrm{MH}$ & 10 & 0 & 0 & 30 & 70 & 0 & Fehren-Schmitz et al., 2010 \\
\hline & Paracas (Palpa) & MH & 28 & 7 & 0 & 14 & 79 & 0 & Fehren-Schmitz et al., 2010 \\
\hline & Nasca-Rural (Palpa) & $\mathrm{EH}$ & 37 & 2 & 11 & 22 & 65 & 0 & Fehren-Schmitz et al., 2010 \\
\hline & Nasca-Urban (Palpa) & MH & 28 & 0 & 18 & 43 & 39 & 0 & Fehren-Schmitz et al., 2010 \\
\hline & Middle Horizon (Palpa) & MH & 11 & 0 & 27 & 36 & 37 & 0 & Fehren-Schmitz et al., 2010 \\
\hline \multirow[t]{7}{*}{ Highlands } & Ancient highlanders & $\mathrm{LH}$ & 35 & 8.5 & 65.7 & 22.9 & 2.9 & 0 & Shinoda et al., 2006 \\
\hline & Pacapaccari & MH & 16 & 0 & 69 & 31 & 0 & 0 & Fehren-Schmitz et al., 2010 \\
\hline & Chen Chen & MH & 23 & 39 & 39 & 17 & 4 & 0 & Lewis Jr., Buikstra and Stone, 2007 \\
\hline & San Martin & M & 22 & 8 & 55 & 5 & 27 & 5 & Fuselli et al., 2003 \\
\hline & Ancash & MH & 33 & 9 & 52 & 18 & 21 & 0 & Lewis Jr. et al., 2007 \\
\hline & Arequipa & M & 22 & 9 & 68 & 14 & 9 & 0 & Fuselli et al., 2003 \\
\hline & Tayacaja & M & 60 & 21 & 33 & 30 & 13 & 3 & Fuselli et al., 2003 \\
\hline
\end{tabular}

*EH: Early Horizon, MH: Middle Horizon, LH: Late Horizon, M: Modern 


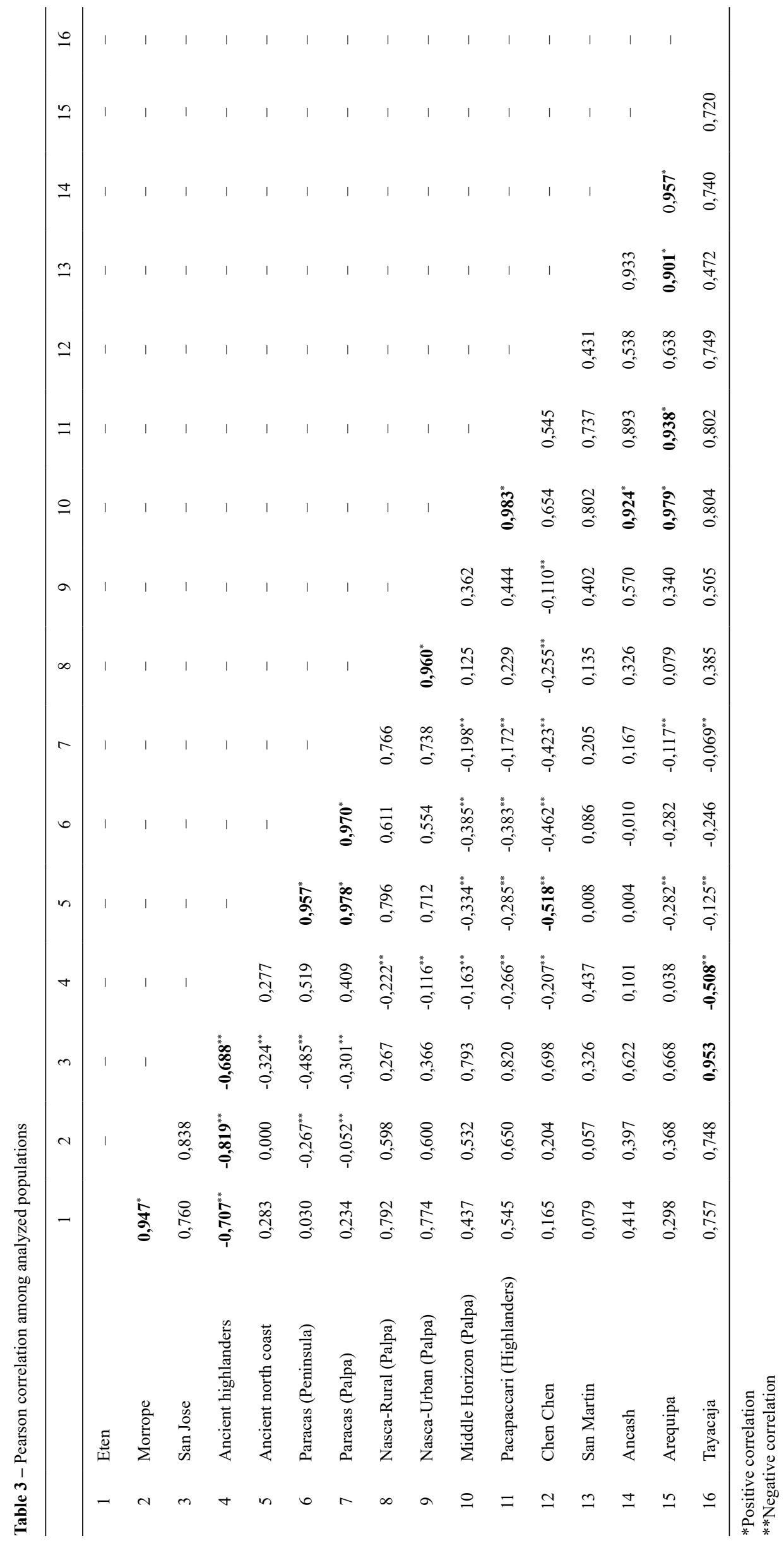




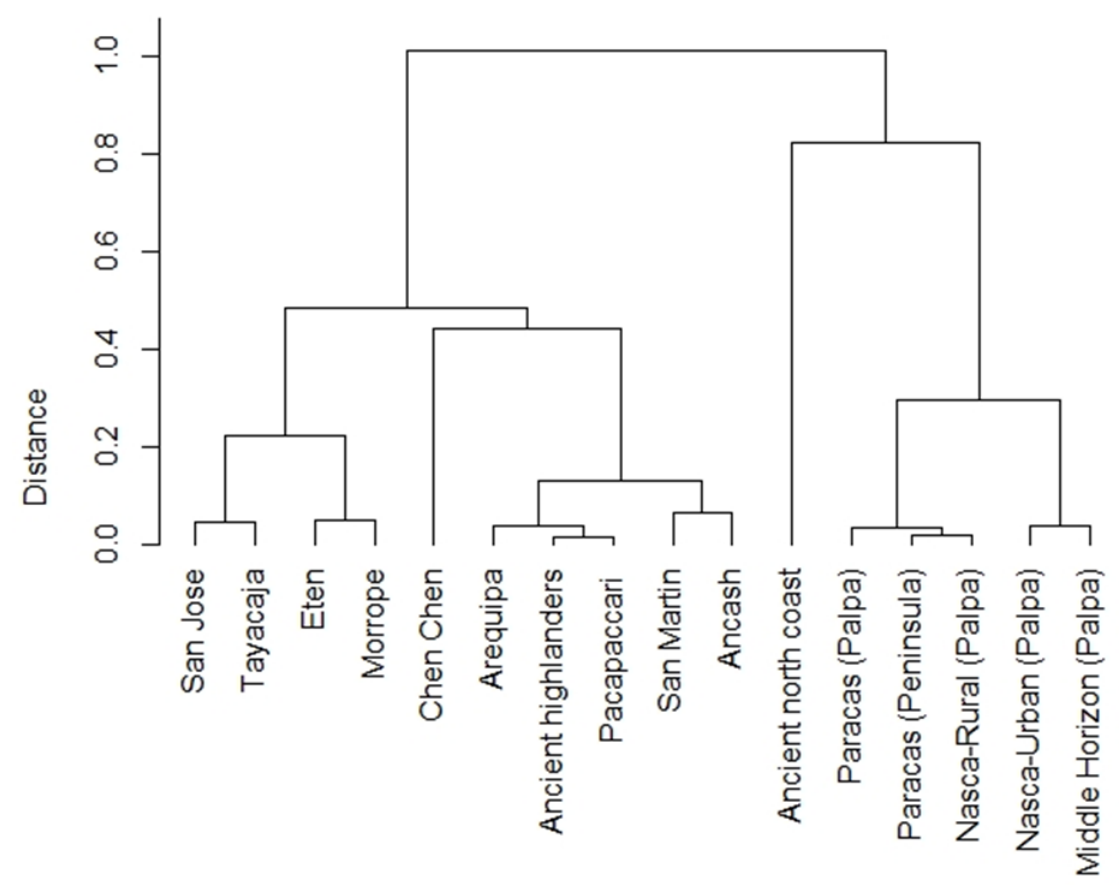

Ancient Populations

hclust (*, "average")

Figure 3 - Hierarchical clustering. UPGMA clustering using haplogroup frequencies of 16 ancient populations.

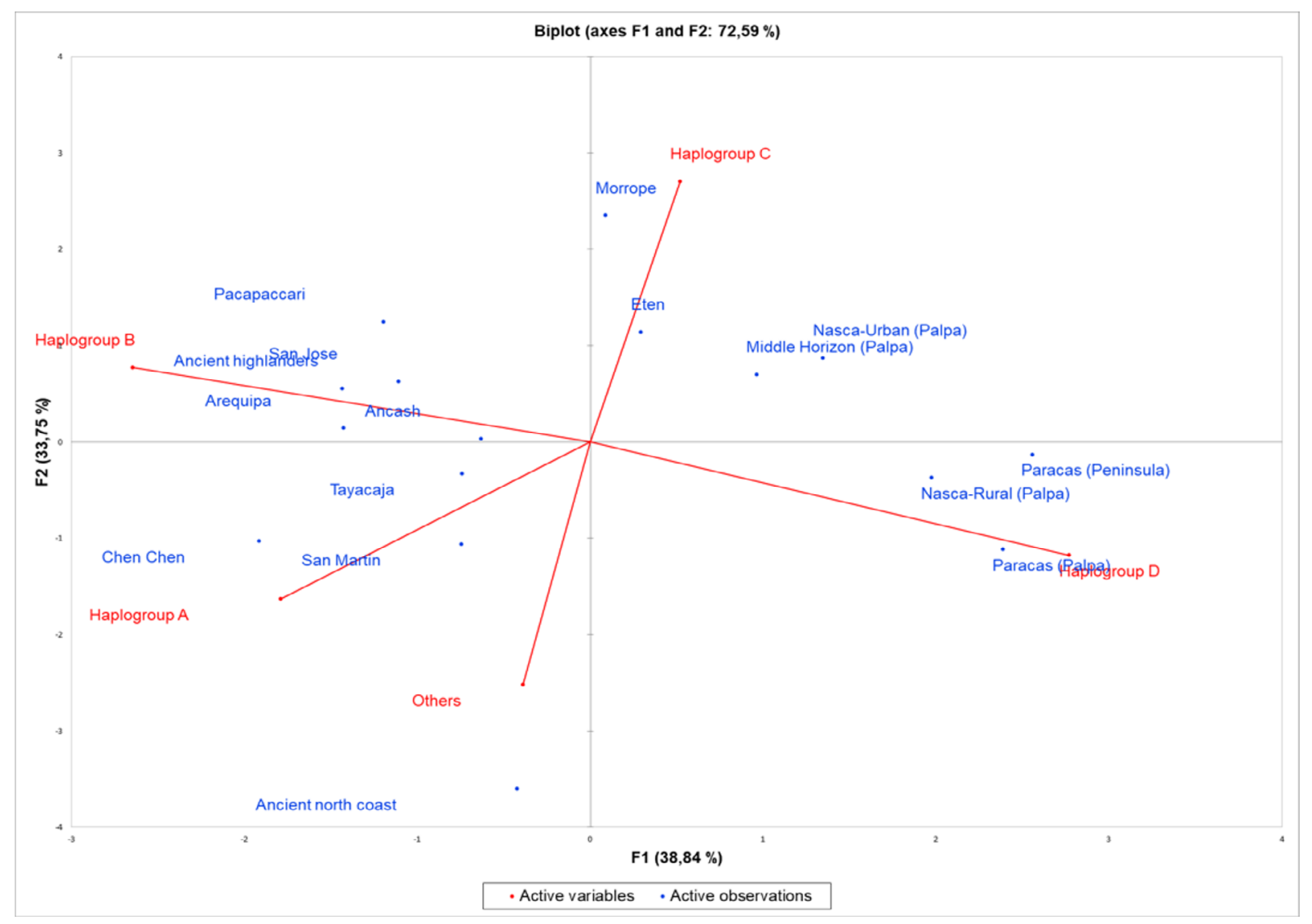

Figure 4 - Principal Component Analysis (PCA) for haplogroup frequencies. PCA graph shows the distribution of the populations among the four Amerindian haplogroups in our meta-analysis. Active variables represent the mitochondrial haplogroups, and active observations represent the analyzed populations. 
Table 4 - AMOVA analysis.

\begin{tabular}{lcccc}
\hline Source of variation & Sum of squares & $\mathrm{df}$ & $\begin{array}{c}\text { Variance } \\
\text { components }\end{array}$ & $\begin{array}{c}\text { Percentage } \\
\text { of variations }\end{array}$ \\
\hline Coastal populations & & & \\
Among groups & 4.712 & 2 & $0.02789 \mathrm{Va}$ & 7.64 \\
Among population within groups & 6.238 & 6 & $0.03772 \mathrm{Vb}$ & 10.33 \\
Within populations & 51.835 & 173 & $0.29962 \mathrm{Vc}$ & 82.04 \\
Highlands populations & & & & \\
Among groups & 16.104 & 2 & $0.06015 \mathrm{Va}$ & 15.27 \\
Among population within groups & 11.153 & 13 & $0.02336 \mathrm{Vb}$ & 5.93 \\
Within populations & 117.360 & 378 & $0.31047 \mathrm{Vc}$ & 78.81 \\
\hline
\end{tabular}

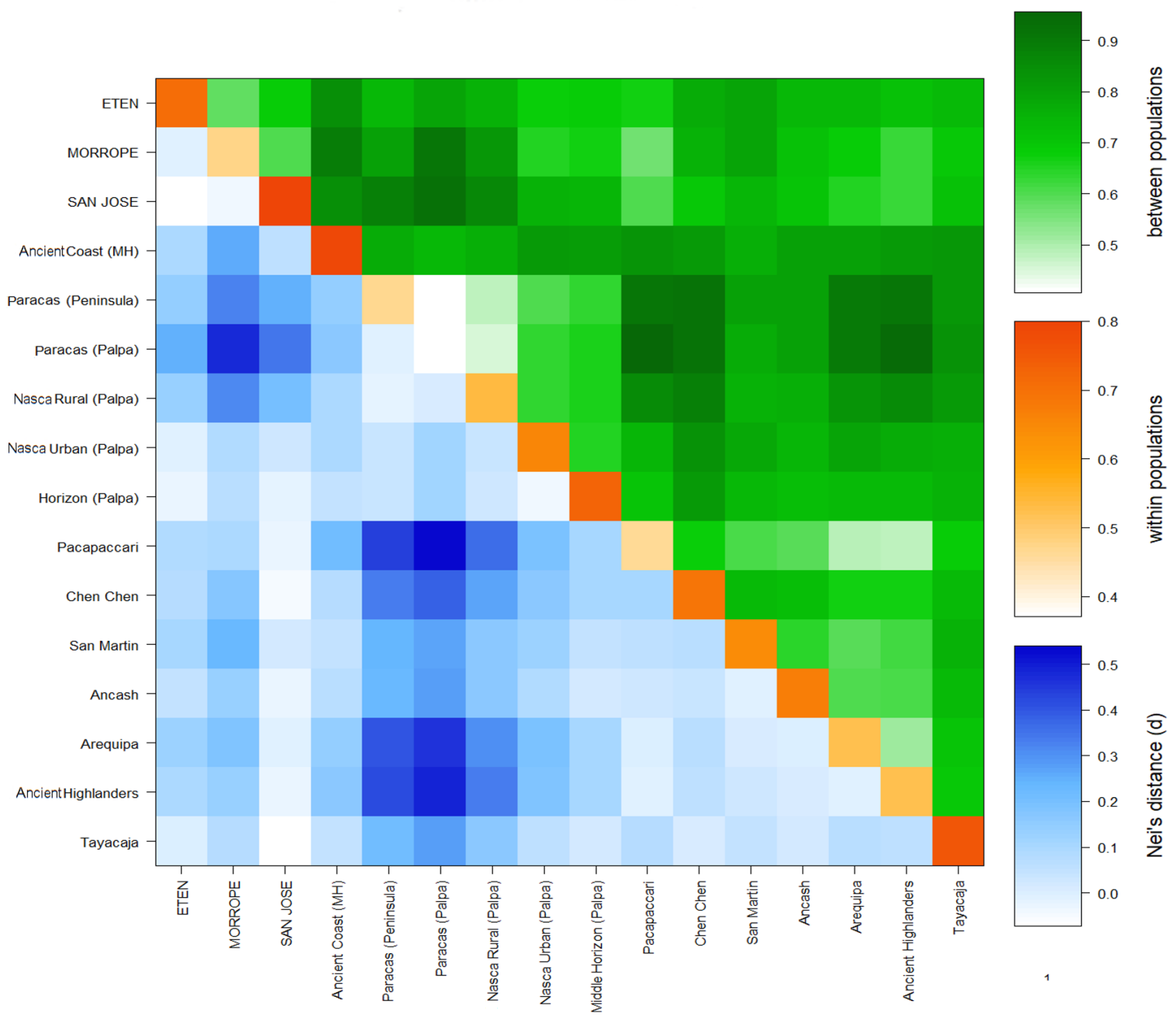

Figure 5 - Average number of pairwise differences. Heatmap showing Nei's distance values against pairwise differences between populations and within populations. 
An increase in haplogroups $\mathrm{C}$ and $\mathrm{D}$ frequencies in our samples suggests a possible predominance of these haplogroups in ancient civilizations from Peruvian coastal populations, since these haplogroups had the highest frequency in ancient populations from the Peruvian south coast (FehrenSchmitz et al., 2010).

The data obtained for each population suggested a possible admixture of populations from the coast and the Andes, as we observed the presence of the four Amerindian haplogroups. Indeed, nowadays, mitochondrial diversity in modern populations from the coast is still maintained (Sandoval et al., 2018).

In addition, the non-exclusive presence of haplogroup $\mathrm{B}$ can be explained by a possible increase in the migration of people from the central Andes to the coast. In fact, the Middle Horizon period (MH: 650-1100 C.E.) was characterized by demographic upheavals that involved the interaction between highland and coastal populations (Valverde et al., 2016).

The samples analyzed in this study belonged to higher periods, from 1200 to 1600 C.E. One example of large changes in the population constitution and social stratification was the colonization of many civilizations settled on the south coast of Peru by the Wari empire (Slovak et al., 2009). The impact of Wari imperialism on the genetic structure of several populations was assessed by the analysis of mitochondrial DNA on boundaries from ancient civilizations, which resulted in the identification of the four mitochondrial Amerindian haplogroups and new haplogroups that had not been reported before (Kemp et al., 2009; Valverde et al., 2016). The presence of these haplogroups supports the hypothesis that an admixture of two populations can lead to novel variations in the human genome over time.

For this reason, genetic analysis of ancient populations is necessary, and our study aims to encourage the study of these civilizations at a molecular level. Unfortunately, sample size in archeological sites does not represent the total number of people who lived in the proximity and could influence haplogroup frequencies, but these results can give us an idea for a possible scenario of maternal legacy that can solve doubts about human diversity and sex characterization on the northern coast of Peru.

\section{Conclusions}

Molecular anthropology studies in the Andes are helping to clarify our understanding of population dynamics in South America. Until now, little was known about the genetic diversity of people from the Lambayeque culture, and we tried to identify a possible maternal line by analyzing boundaries from archeological sites of three localities where this culture settled. We compared our results with previous mitochondrial DNA characterizations of populations from the Peruvian coast to investigate the variation of haplogroups among these populations. Even though our sample is not enough to establish associations between a civilization and an Amerindian haplogroup or among samples, we were able to infer a possible distribution of these haplogroups in the Peruvian coast based on our statistical analysis. For instance, ancient people in Lambayeque presented the four analyzed haplogroups with an increase in haplogroups $\mathrm{C}$ and
B, which correlated with the findings in other ancient coastal Peruvian populations. Molecular analysis of mitochondrial DNA haplogroups helped to identify polymorphisms shared among samples of ancient human populations that had not been characterized previously. However, this analysis must be complemented with other molecular assays, such as polymorphisms in chromosome $\mathrm{Y}$, to establish an exact kinship among samples.

\section{Acknowledgments}

We thank Professor Dr Kuruvilla Joseph Abraham for verifying the statistical analysis of the data. We like to thank Editage (www.editage.com) for English language editing.

\section{Conflict of Interest}

The authors declare that they have no conflicts of interest.

\section{Author Contributions}

JVWCW and LARD designed the study, analyzed the data, and drafted and edited the manuscript for intellectual content; JVCW preformed PCR-RFLP experiments, while VJSV performed amelogenin gene characterization; CEWLT performed the archeological characterization of the samples and contributed to the manuscript editing.

\section{References}

Cabana GS, Lewis CM, Tito RY, Alan Covey R, Cáceres AM, De La Cruz AF, Durand D, Housman G, Hulsey BI, Iannacone GC et al. (2014) Population genetic structure of traditional populations in the peruvian central andes and implications for South American population history. Hum Biol 86:147-165.

Castillo LJ and Donnan CB (1994) La ocupación moche de San José de Moro, Jequetepeque. Moche Propuestas y Perspect 79:93-146.

Eshleman JA, Malhi RS and Smith DG (2003) Mitochondrial DNA Studies of Native Americans: Conceptions and misconceptions of the population prehistory of the Americas. Evol Anthropol 12:7-18.

Excoffier L and Lischer HEL (2010) Arlequin suite ver 3.5: A new series of programs to perform population genetics analyses under Linux and Windows. Mol Ecol Resour 10:564-567.

Fehren-Schmitz L, Reindel M, Cagigao ET, Hummel S and Herrmann B (2010) Pre-Columbian population dynamics in coastal southern Peru: A diachronic investigation of mtDNA patterns in the Palpa region by ancient DNA analysis. Am J Phys Anthropol 141:208-221.

Fuselli S, Tarazona-Santos E, Dupanloup I, Soto A, Luiselli D and Pettener D (2003) Mitochondrial DNA diversity in South America and the genetic history of andean highlanders. Mol Biol Evol 20:1682-1691.

Kemp BM, Tung TA and Summar ML (2009) Genetic continuity after the collapse of the Wari empire: Mitochondrial DNA profiles from Wari and post-Wari populations in the ancient andes. Am J Phys Anthropol 140:80-91.

Klaus HD and Tam ME (2009) Contact in the Andes: Bioarchaeology of systemic stress in colonial Mórrope, Peru. Am J Phys Anthropol 138:356-368.

Klaus HD, Larsen CS and Tam ME (2009) Economic intensification and degenerative joint disease: Life and labor on the postcontact north coast of Peru. Am J Phys Anthropol 139:204-221.

Klaus HD, Turner BJ, Saldaña F, Castillo S and Wester C (2016) Human sacrifice at the Chotuna-Chornancap archaeological complex: Traditions and transformations of ritual violence under Chimú 
and Inka rule. In: Klaus HD and Toyne JM. Ritual violence in the ancient Andes: Reconstructing sacrifice on the north coast of Peru. University of Texas Press, Austin, pp 178-210.

Lê S, Josse J and Husson F (2008) FactoMineR: an R package for multivariate analysis. J Stat Softw 25:1-18.

Lewis Jr. CM, Buikstra JE and Stone AC (2007) Ancient DNA and genetic continuity in the south central Andes. Lat Am Antiq 18:145-160.

Lüdecke D, Waggoner PD and Makowski D (2019) Insight: A unified interface to access information from model objects in R. J Open Source Softw 4:1412.

Merriwether DA, Rothhammer F and Ferrell RE (1994) Genetic variation in the New World: Ancient teeth, bone, and tissue as sources of DNA. Experientia 50:592-601.

Merriwether DA, Rothhammer F and Ferrell RE (1995) Distribution of the four founding lineage haplotypes in Native Americans suggests a single wave of migration for the New World. Am J Phys Anthropol 98:411-430.

Moraga M, Aspillaga E, Santoro C, Standen V, Carvallo P and Rothhammer F (2001) Análisis de ADN mitocondrial en momias del norte de Chile avala hipótesis de origen amazónico de poblaciones andinas. Rev Chil Hist Nat 74:719-726.

Morikawa T, Yamamoto Y and Miyaishi S (2011) A new method for sex determination based on detection of SRY, STS and amelogenin gene regions with simultaneous amplification of their homologous sequences by a multiplex PCR. Acta Med Okayama 65:113-122.

Nakatsuka N, Lazaridis I, Barbieri C, Skoglund P, Rohland N, Mallick S, Posth C, Harkins-Kinkaid K, Ferry M, Harney É et al. (2020) A paleogenomic reconstruction of the deep population history of the andes. Cell 181:1131-1145.

Rodriguez-Delfin LA, Rubin-de-Celis VE and Zago MA (2001) Genetic diversity in an Andean population from Peru and regional migration patterns of Amerindians in South America: Data from Y chromosome and mitochondrial DNA. Hum Hered 51:97-106.

Sandoval J, Lacerda D, Jota M, Salazar-Granara A, Vieira P, Acosta O, Cuellar C, Revollo S, Fujita R and Santos F (2013) The genetic history of indigenous populations of the Peruvian and Bolivian Altiplano: the legacy of the Uros. PLoS One 8:e73006.

Sandoval JR, Lacerda DR, Jota MS, Elward R, Acosta O, Pinedo D, Danos P, Cuellar C, Revollo S, Santos FR et al. (2018) Genetic ancestry of families of putative Inka descent. Mol Genet Genomics 293:873-881.
Shimada I, Shinoda K, Farnum J, Corruccini R and Watanabe H (2004) An integrated analysis of pre-hispanic mortuary practices. Curr Anthropol 45:369-402.

Shinoda K, Adachi N, Guillen S and Shimada I (2006) Mitochondrial DNA analysis of ancient Peruvian highlanders. Am J Phys Anthropol 131:98-107.

Slovak NM, Paytan A and Wiegand BA (2009) Reconstructing Middle Horizon mobility patterns on the coast of Peru through strontium isotope analysis. J Archaeol Sci 36:157-165.

Torroni A and Wallace DC (1995) MtDNA haplogroups in Native Americans. Am J Hum Genet 56:1234.

Valverde G, Romero MIB, Espinoza IF, Cooper A, Fehren-Schmitz L, Llamas B and Haak W (2016) Ancient DNA analysis suggests negligible impact of the Wari empire expansion in Peru's Central Coast during the Middle Horizon. PLoS One 11: e0155508.

Wester La Torre C, Castillo Reys S and Saldaña Camacho F (2014) Escenarios de poder y espacios ceremoniales: el trono y la residencia de élite en Chornancap, cultura Lambayeque. In: Fernández Alvarado JC and Wester La Torre C (eds). Cultura Lambayeque en el contexto de la costa norte del Perú. Emdecosege, Chiclayo, Peru, pp 271-309

\section{Supplementary material}

The following online material is available for this article: Table S1 - Primer sequences for PCR amplification.

Table S2 - Primer sequences for PCR amplification of amelogenin gene.

Table S3 - Sample codes and results for Eten.

Table S4 - Sample codes and results for Morrope.

Table S5 - Sample codes and results for San Jose.

Figure S1 - PCR amplification and restriction enzyme digestion of ancient DNA.

Associate Editor: Fabrício Rodrigues dos Santos

License information: This is an open-access article distributed under the terms of the Creative Commons Attribution License (type CC-BY), which permits unrestricted use, distribution and reproduction in any medium, provided the original article is properly cited. 